\title{
Slab Width Control for Hot Direct Rolling*
}

\author{
By Shunji NAKAMURA, ,* Michiaki TAKAHASHI,** Yuji CHIDA, ** \\ Takashi SEKI** and Yukio WAKAMATSU**
}

\begin{abstract}
Synopsis
Muroran Works of Nippon Steel Corp. formerly sized continuously cast slabs at a breakdown mill before transfer to the hot strip mill. Slabs must be continuously cast with such a width as required by the hot strip mill if they are to be sent directly to the hot strip mill without sizing.

When slabs of a given width were continuously cast at a high speed, the width fluctuates greatly at the exit of caster and sometimes exceeds the allowable slab width at the hot strip mill.

Muroran Works developed a constant slab width control model that uses a width changing device to minimize the slab width fluctuation at the continuous caster; a hot slab width meter of the contact type that can level the edge profile of slab to increase the allowable range of slab width at the hot strip mill; and a roughing edger setup model that can make the most of the small capacity of the roughing edger at the hot strip mill.

As a result, it became possible to supply the hot strip mill with slabs directly from the continuous caster when a powerful vertical scalebreaker or sizing mill is not available. The models and instruments developed are described.
\end{abstract}

Key words: continuous casting; hot direct rolling; sizing mill; vertical scalebreaker; slab width meter; slab width control; mold width changing device; computer control.

\section{Introduction}

In hot direct rolling process at Oita, Sakai and Muroran Works of Nippon Steel Corporation, various techniques are successfully employed for producing high quality and high temperature castings and for high speed slab width alteration, ${ }^{1,2)}$

Recently Muroran Works have developed a new technique for slab width control besides those techniques. The new technique has eliminated the necessity for the use of a sizing mill or vertical scalebreaking equipment in hot direct rolling process. Considerable saving has been attained in total process costs through the use of this technique.

This report presents the three elements of the slab width control technique: a constant slab width control model, a contact-type hot slab width meter for averaging edge profile of a slab and a hot roughing edger setup model.

\section{Background of Development}

The introduction of a variable width mold changed the slab casting conditions, as listed in Table 1 . When a casting test was conducted under the new conditions, the variable range of slab width amounted to about $50 \mathrm{~mm}$ at the exit of the caster $(70 \mathrm{~mm}$ when the width difference between cast slabs was taken into account) and exceeded the maximum allowable range of slab width variation $( \pm 5 \mathrm{~mm} \sim 0-10 \mathrm{~mm})$ at the hot strip mill, as shown in Fig. 1.

Slab width varies with deformation due to bulging and compressive force, which are affected by casting speed and braking force during compression casting (GPC) as shown in Fig. 2.

The controlling factors of slab width were analyzed. Development work was started to send slabs directly from the continuous caster to the hot strip mill by minimizing the slab width fluctuations and increasing the maximum range of allowable slab width at the hot strip mill.

\section{Development of Slab Width Control Tech- niques}

To supply slabs directly from a continuous caster to a hot strip mill where is not vertical scalebreaker or sizing mill, the techniques, listed in Fig. 3, were developed to minimize the width fluctuations of continuously cast slabs and to increase the slab width range allowable at the hot strip mill.

\section{Minimization of Slab Width Fluctuation at Caster}

The width of continuously cast slabs depends primarily on the width of mold in the caster and changes with the operating conditions of the caster.

A control model for constant slab width continuously controls the mold width by using a slab width changing device. It was developed by incorporating the steel grade, casting speed, and compressive force, which are the three control factors that have an especially large effect on the slab width variation in ac-

Table 1. Changes in slab casting conditions.

\begin{tabular}{|l|l|}
\hline SIZING MILL & USED $\rightarrow$ NOT USED \\
\hline Thickness & $350 \mathrm{~mm} \rightarrow 250 \mathrm{~mm}$ \\
\hline Width & $\begin{array}{l}\text { Fixed at } 1000 \text { and } 1300 \mathrm{~mm} \rightarrow \text { Variable over } \\
\text { range of } 570 \text { to } 1300 \mathrm{~mm}\end{array}$ \\
\hline Casting speed & $1.0 \mathrm{~m} / \mathrm{min} \rightarrow 1.6 \mathrm{~m} / \mathrm{min}$ \\
\hline
\end{tabular}

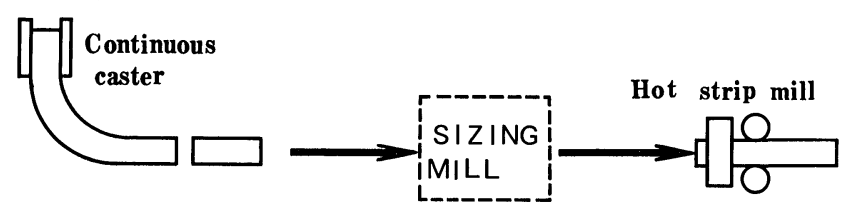

* Based on the papers presented to the 112th ISIJ Meeting, October 1986, S978 and S1231, at Nagoya University in Nagoya. Manuscript received on April 13, 1987; accepted in the final form on September 11, 1987 . (C) 1988 ISIJ

** Muroran Works, Nippon Steel Corporation, Nakamachi, Muroran 050. 
Fig. 1.

Actual example of slab width fluctuation.
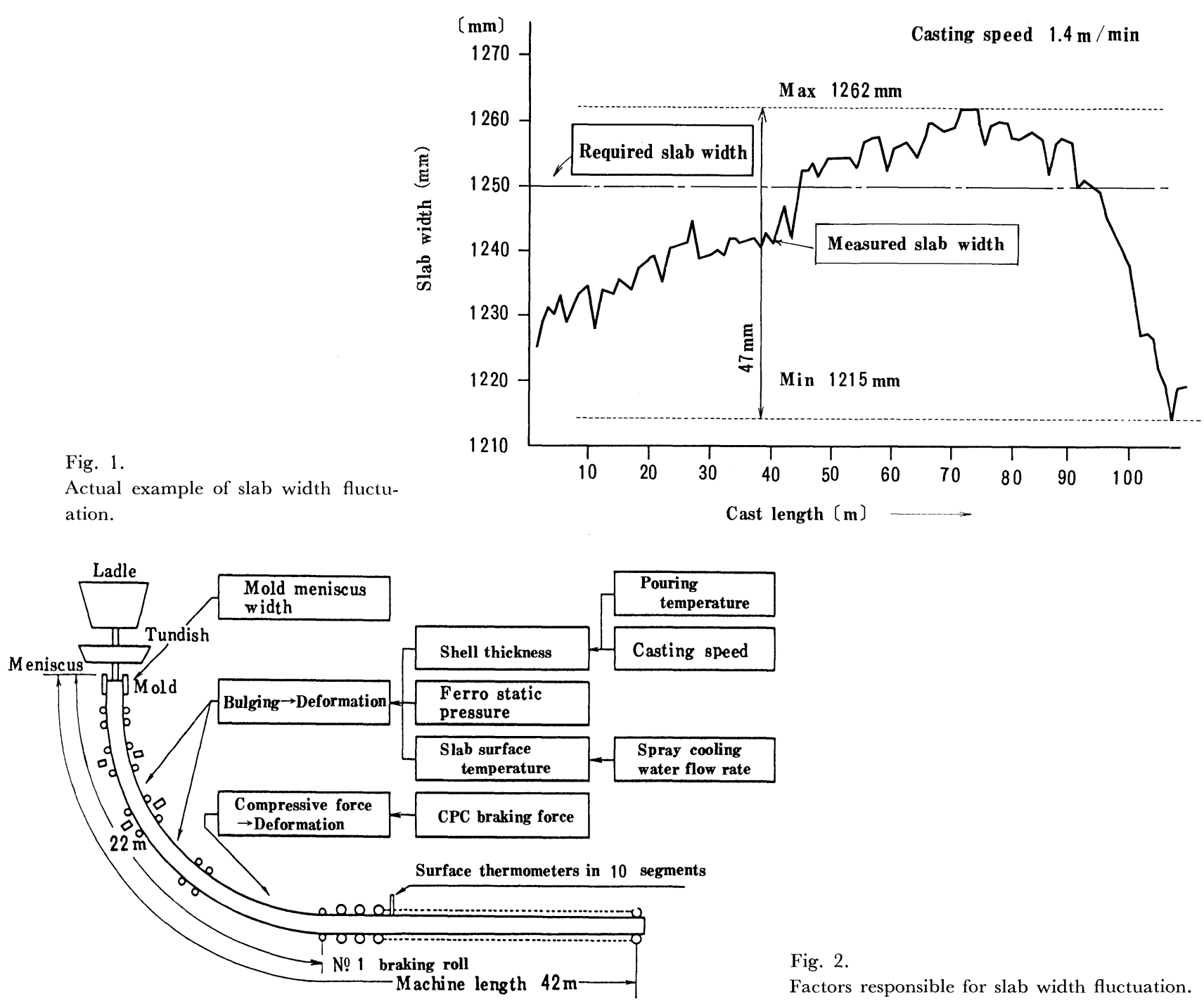

Fig. 2.

Factors responsible for slab width fluctuation.

\begin{tabular}{llll}
\hline \multicolumn{1}{c}{ Concept } & $\begin{array}{l}\text { Technique to } \\
\text { be developed }\end{array}$ & \multicolumn{1}{c}{$\begin{array}{c}\text { Description of } \\
\text { technique }\end{array}$} & $\begin{array}{c}\text { Result of } \\
\text { development }\end{array}$ \\
\hline $\begin{array}{l}\text { Minimize slab width varia- } \\
\text { tion at caster }\end{array}$ & $\begin{array}{l}\text { Constant slab } \\
\text { width control } \\
\text { model }\end{array}$ & $\begin{array}{l}\text { Constant slab width } \\
\text { control with width } \\
\text { changing device } \\
\text { used as final detect- } \\
\text { ing element }\end{array}$ & $70 \rightarrow 30 \mathrm{~mm}$ \\
$\begin{array}{llll}\text { Increase maximum allowa- } \\
\text { ble range of slab width var- } \\
\text { iation at hot strip mill (It is } \\
\text { difficult to increase edger } \\
\text { capacity.) }\end{array}$ & Slab width & $\begin{array}{l}\text { Hot slab width me- } \\
\text { mer of low cost and } \\
\text { high performance }\end{array}$ & \\
\cline { 2 - 3 } & Roughing edger & $\begin{array}{l}\text { High-accuracy mod- } \\
\text { el to make most of } \\
\text { edger capacity }\end{array}$ & \\
\hline
\end{tabular}

Fig. 3.

Techniques to be developed for slab width control.

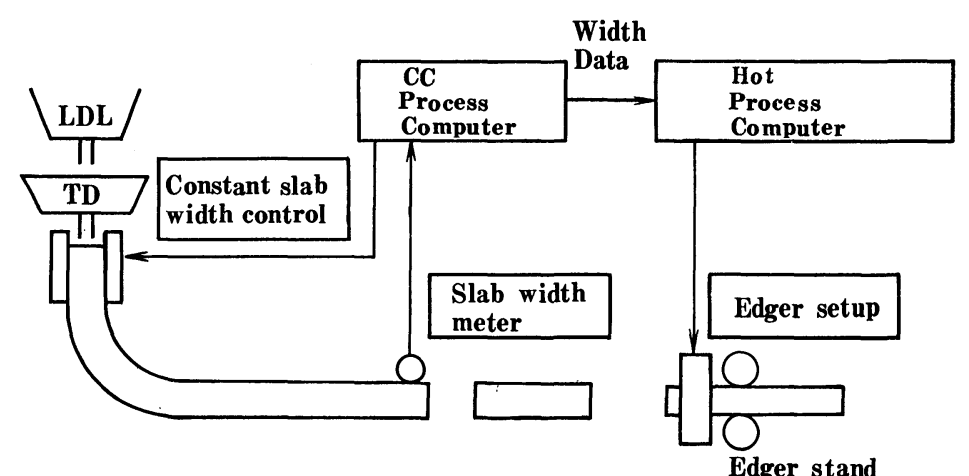


cordance with the width of mold of caster.

\section{Expansion of Maximum Range of Slab Width Varia-} tion Allowable at Hot Strip Mill

(1) Such a non-contact slab width meter as the laser type is not effective for measuring the change in edge profile of continuously cast slabs. A hot slab width meter of the contact type was thus developed for leveling and measuring the edge profile of a casting slab.

(2) Two models were developed; a setup logic that takes into account the load distribution per pass to make the most of the small capacity of roughing edger and a roughing edger setup model that performs a learning according to the measured edger motor current to increase the accuracy of the model without load cells or exit width meters. These techniques helped to expand the maximum range of slab width variation allowable at the hot strip mill without a drop in finishing accuracy.

\section{Development of Control Model for Constant Slab Width}

\section{Concept of Constant Slab Width Control}

The control model for constant slab width is characterized by the incorporation of steel grade, casting speed and compressive force, which are the three fac- tors that have an especially large effect on the slab width variation as control factors, and by the continuous control of the mold width by the use of a slab width changing device. The movement of the mold during application of the constant slab width control model is explained below.

According to the results of analysis of the slab width variation with slab portion, the control model for constant slab width divides the slab of various steel grade into 4 portions as shown in Table 2 and controls its width as described below and as shown in Fig. 4.

(a) The mold is set at a width larger than the required width of slab at the start of casting and is slowly narrowed to balance the increase in width of

Table 2. Results of analysis of slab width variation by slab portion.

\begin{tabular}{|c|c|c|}
\hline $\begin{array}{l}\text { B } 1 \\
\text { portion }\end{array}$ & $\begin{array}{l}\text { Rapid width variation } \\
\text { at start of casting }\end{array}$ & $\begin{array}{l}\text { About } 7 \mathrm{~m} \\
\text { Related to high casting } \\
\text { speed at start of casting }\end{array}$ \\
\hline $\begin{array}{l}\text { B } 2 \\
\text { portion }\end{array}$ & Slow width variation & $\begin{array}{l}\text { About } 40 \mathrm{~m} \text { (machine } \\
\text { length } 42 \mathrm{~m} \text { ) } \\
\text { Change in line resistance }\end{array}$ \\
\hline $\begin{array}{l}\text { M } \\
\text { portion }\end{array}$ & & $\begin{array}{l}\text { Can be explained by } \\
\text { casting speed and CPC } \\
\text { braking force }\end{array}$ \\
\hline $\begin{array}{l}\mathrm{T} \\
\text { portion }\end{array}$ & $\begin{array}{l}\text { Slow width decrease } \\
\text { at and of casting }\end{array}$ & $\begin{array}{l}\text { Starting at } 24 \mathrm{~m} \text { position } \\
(22 \mathrm{~m} \text { to braking roll }) \\
\text { Effect of CPC force }\end{array}$ \\
\hline
\end{tabular}
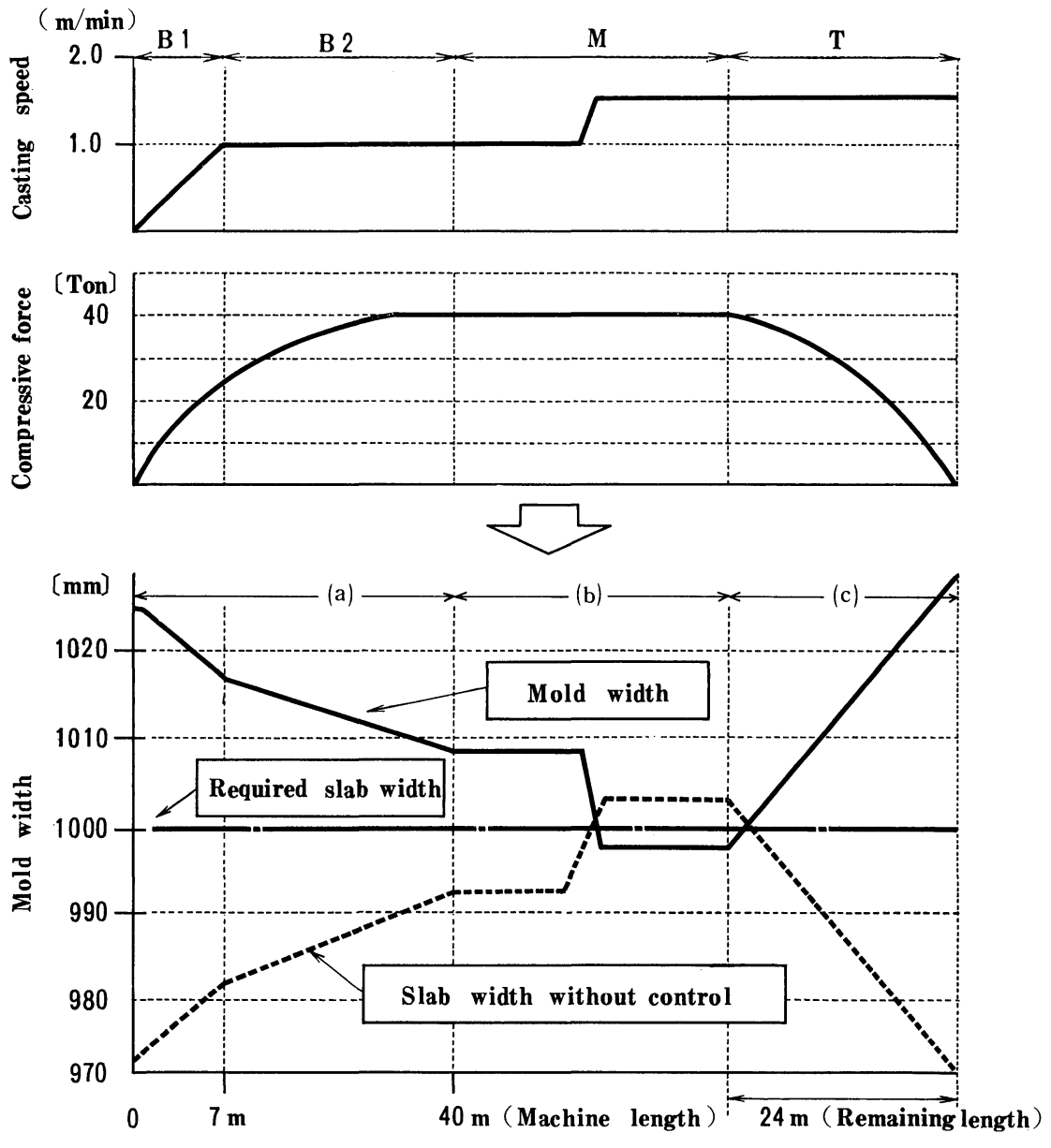

Cast length $[\mathrm{m}] \longrightarrow$
Fig. 4.

Control method for constant slab width. 
the slab with increasing casting speed and compressive force, as shown for the B1 and B2 portions in Fig. 4. The mold width at the start of casting is given as the ratio of required slab width to shrinkage coefficient of the head end.

(b) When the casting speed or compressive force changes during cast, the mold width is controlled to allow for the amount of change, as shown for the $M$ portion in Fig. 4. The mold width in this steadystate region is given as the ratio of required width of slab to

$$
\left(\beta_{0}+\beta_{1} \times v \times \beta_{1} \times c p c\right)
$$

where, $\beta_{0}$ : shrinkage coefficient of slab in steady state

$\beta_{1}$ : casting speed coefficient

$\beta_{2}$ : compression coefficient

v: casting speed

$c p c$ : compressive force.

The values of $\beta_{0}, \beta_{1}$ and $\beta_{2}$ are calculated from the multiple regression analysis. Independent variables are $V, c p c$ and dependent variable is the ratio of measured slab width to mold width.

(c) At the end of casting, the mold is slowly widened to balance the decrease in slab width with decreasing ferrostatic pressure and compressive force, as shown for the $\mathrm{T}$ portion in Fig. 4. The mold width at the end of casting is the ratio of required width of slab to shrinkage coefficient of the tail end.

\section{Relations between Slab Width Change and Constant Slab Width Control}

If the mold width must be changed to meet the slab width demanded by the hot strip mill, priority is given to the mold width change. Therefore, by control of constant slab width the mold width actually changes as illustrated in Fig. 5.

\section{Results of Control of Constant Slab Width}

To produce a slab of a constant width, the mold

width was controlled by $7 \mathrm{~mm}$ in the $\mathrm{Bl}$ portion, $19 \mathrm{~mm}$ in the $\mathrm{B} 2$ portion, $40 \mathrm{~mm}$ in the $\mathrm{T}$ portion and $12 \mathrm{~mm}$ in the casting speed change portion. As a result, the measured slab width is controlled within $10 \mathrm{~mm}$ of the target slab width (required slab width), as shown in Fig. 6.

\section{Development of Hot Slab Width Meter for Leveling Edge Profile of Slab}

\section{Outline}

The slab width meter may be divided into the slab contact part consisting of touch rolls, the drive part mainly composed of air cylinders and the measuring part chiefly comprising a rotary encoder, as shown in Fig. 7. The principle of measurement is simply to bring the touch rolls into contact with each edge of the casting slab by an air cylinder and subtracting the amounts of cylinder rod movement, $X$ and $Y$, from the distance, $L$, from a known origin, to determine the width of the slab. The features of the slab width

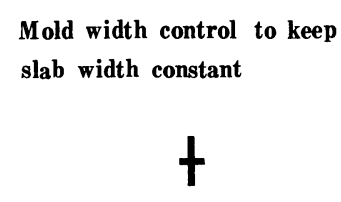

Mold width control to meet required slab width

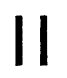

Actual mold width control
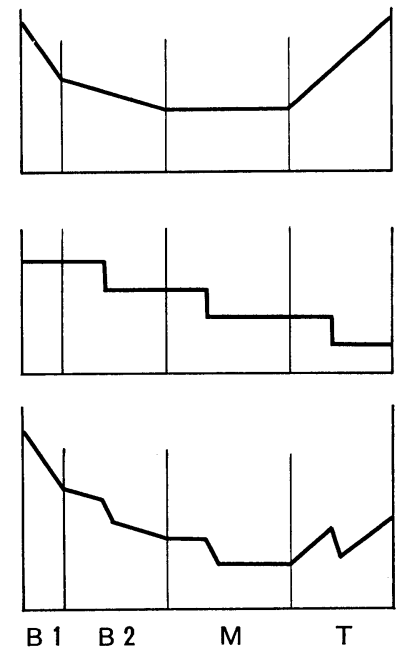

Fig. 5. Scheme of control for constant width.
Fig. 6.

Example of control for constant slab width.

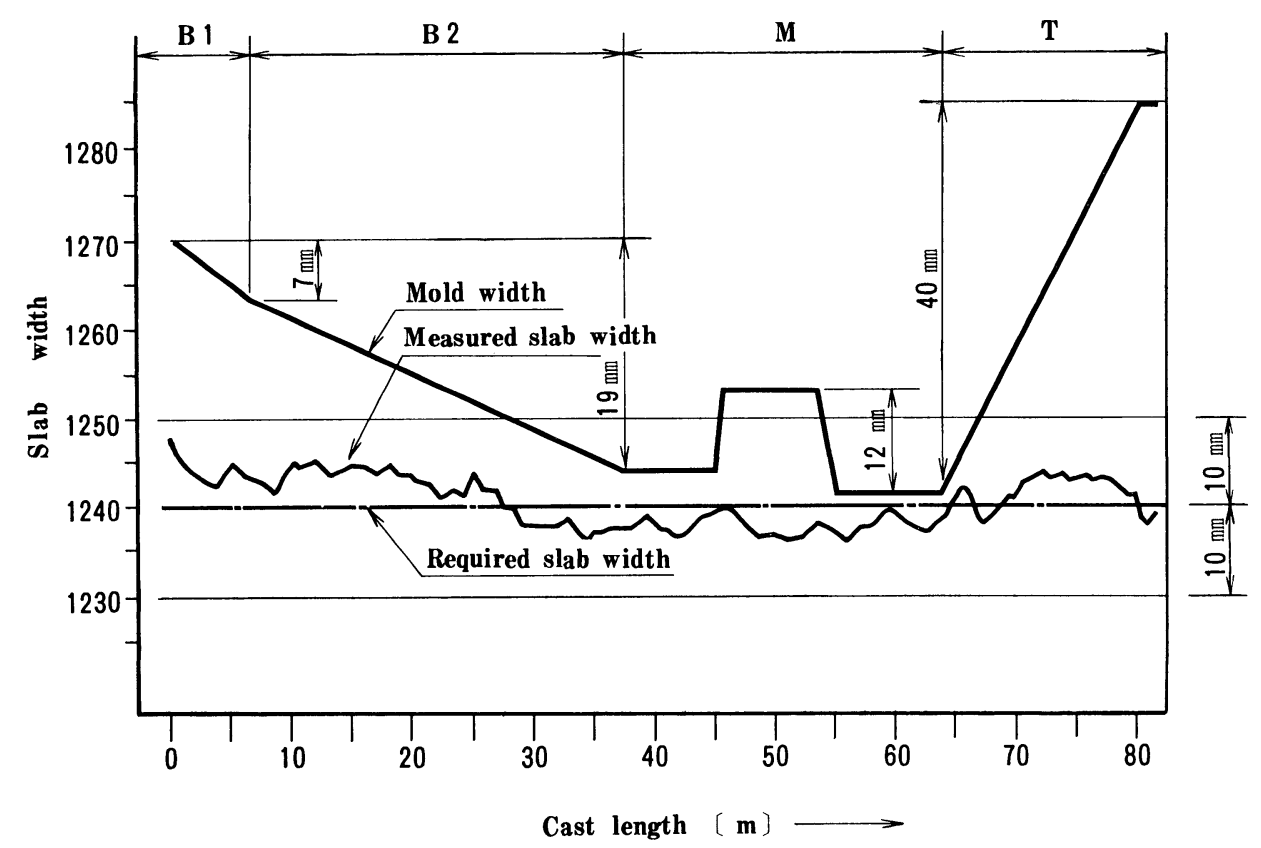

Technical Report 


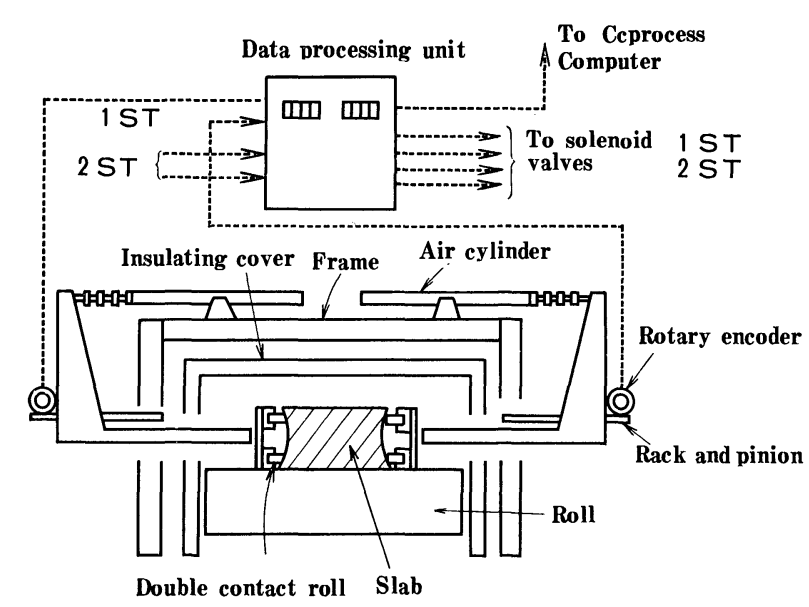

Fig. 7. Construction of slab width meter.

meter are: (1) the slab width can be measured without adverse effects of the scale formed on slab edge and by the edge profile of slab; and (2) the equipment cost is lower than in the case with a non-contact width meter. The prototype was built by considering the following points :

1) Reduction in touch roll contact time by periodic measurement

2) Reduction in roll wear by adoption of rotary touch rolls

3) Uniform thermal expansion and bias compensation by water cooling of the frame and other structural parts

4) Zero compensation function in standby position for each cycle of cylinder operation

5) Assurance of a certain measurement timing by timer check

6) Double contact rolls for following accurately the edge profile of slab.

The slab edge profile varies as much as $10 \mathrm{~mm}$ as shown in Fig. 8. This variation must be leveled to obtain the width of slab. The accuracy of the slab width meter can be maintained over a long period by an on-line calibration device that inserts a test piece into the meter. Due consideration is also given to maintenance.

\section{Accuracy of Measurement}

The expected accuracy of the slab width meter may be represented as the sum of (1) thermal expansion of the mechanical system and (2) mechanical backlash besides measurement error. The first component is bias, and the second component is a statistical error.

The accuracy of off-line measurement (cold measurement) is within $\pm 0.2 \mathrm{~mm}$ and virtually agrees with the value of $\pm 0.2 \mathrm{~mm}$ for the second component of accuracy noted above. The accuracy of on-line measurement (hot measurement) is held within $\pm 2 \mathrm{~mm}$, as shown in Fig. 9.

\section{Development of Roughing Edger Setup Model}

Two types of models were developed; a roughing edger setup logic that optimizes the load distribution

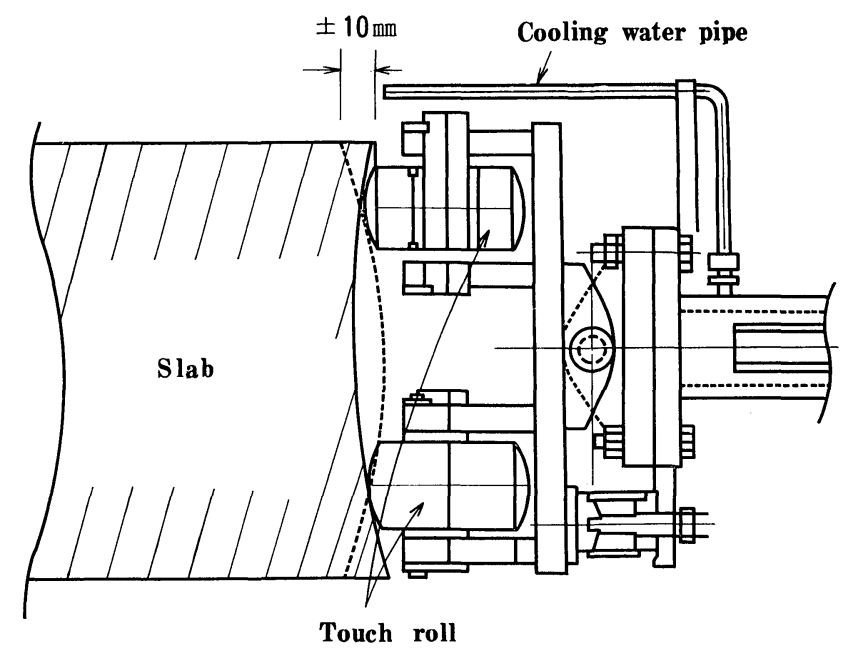

Fig. 8. Construction of touch rolls.
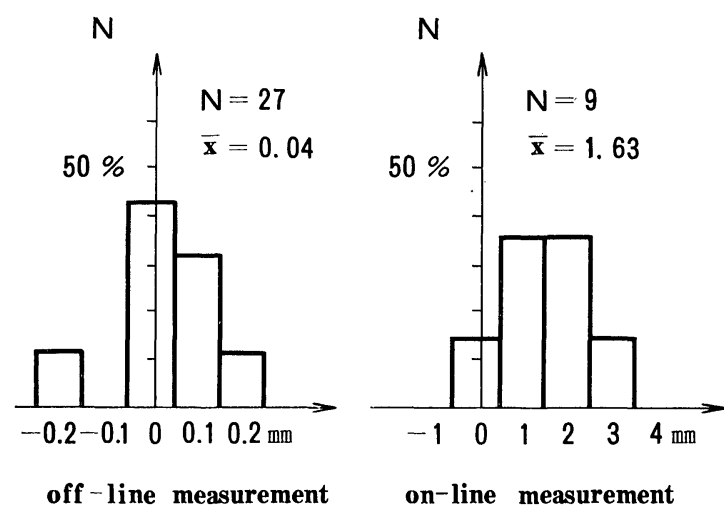

Fig. 9. Measurement accuracy of slab width meter.

in each pass in order to make the most of the small capacity of roughing edger and a roughing edger setup model that performs a learning according to the measured edger motor current for enhanced accuracy of the model without load cells or width meters in the roughing mill.

\section{Material Flow and Accept / Reject Judgment}

When a slab reaches the transfer line, its width is judged to see if it can be accepted at the hot strip mill according to the width measured with the hot slab width meter. When its width is judged to be unacceptable, the slab is rejected from the transfer line. When its width is judged to be acceptable, the slab is carried away by a slab car from the transfer line and is charged into the reheating furnace to be rolled at the hot strip mill, as shown in Fig. 10.

\section{Roughing Edger Setup Model}

The slabs received directly from the continuous caster greatly fluctuate in width. Since the roughing edger had an insufficient capacity and was not equipped with a load cell or exit width meter, a high-accuracy model was required for making the most of the available capacity of roughing edger. The model includes the torque limit $E_{1}$, load limit $E_{2}$ and buck- 

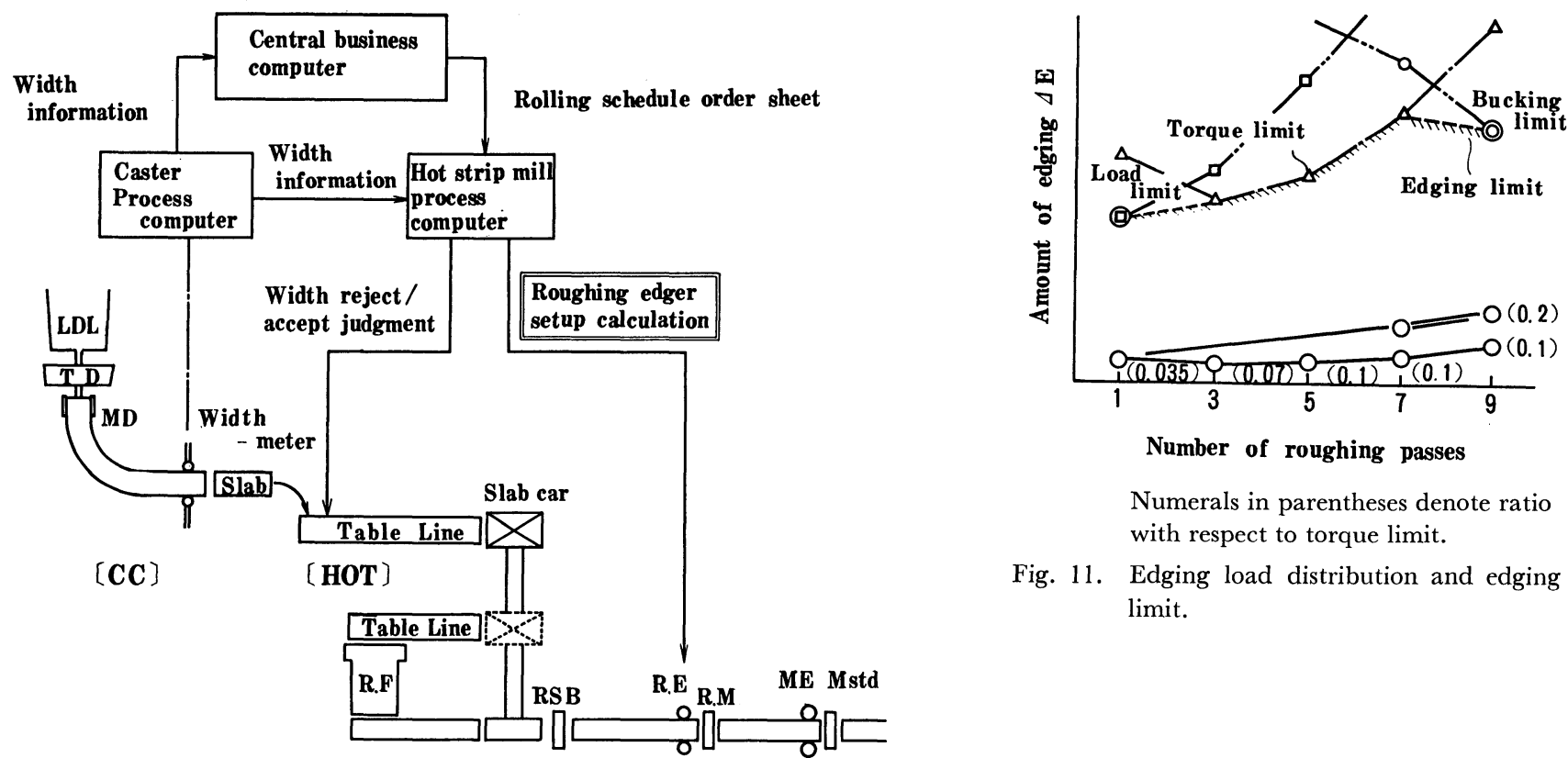

Numerals in parentheses denote ratio with respect to torque limit.

Fig. 11. Edging load distribution and edging limit.

Width information
(1) Minimum value
(2) Maximum value
(4) Head-end width
(5) Tatil-end width
(3) Mean value

Fig. 10. Equipment layout and system functions from continuous caster to hot strip mill.

Fig. 12.

Optimization of model equation and uniform load distribution.

\section{[Optimization of model equation]}
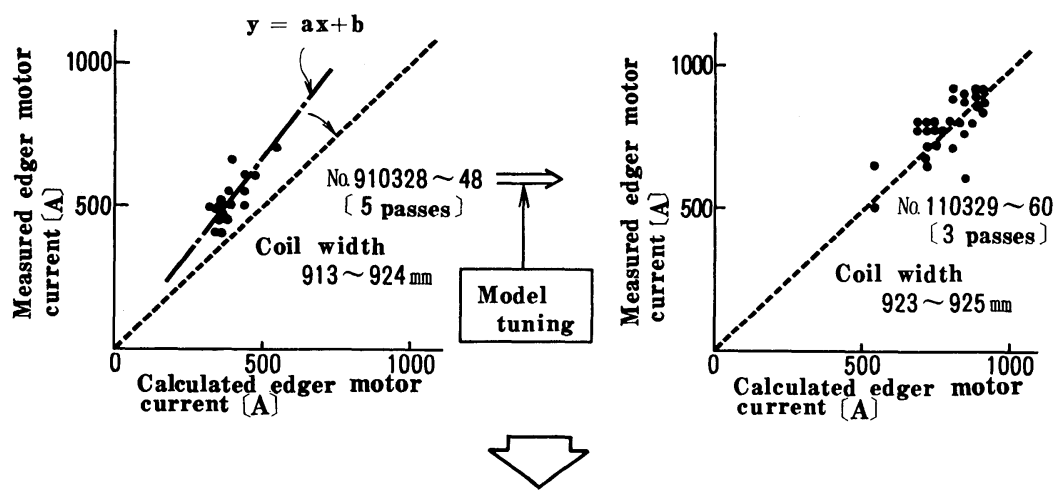

[Results of model application〕 Uniform load distribution by increase in load on last stands
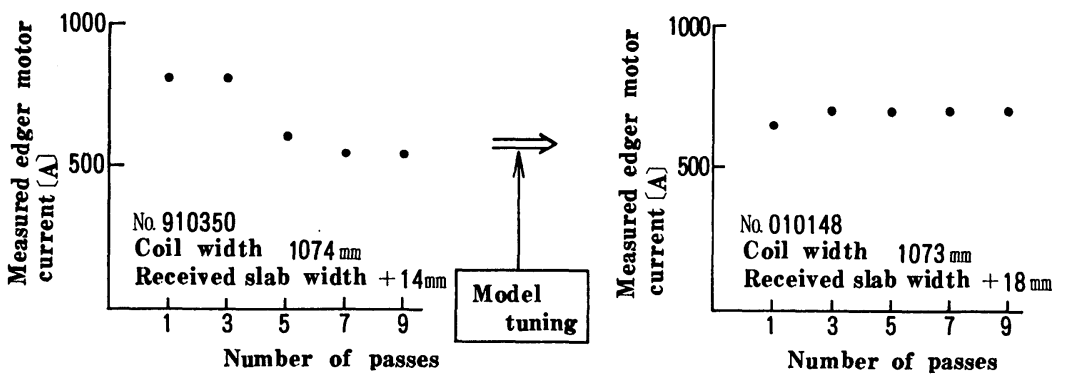

$$
\begin{aligned}
& \underset{\text { Operator control }}{\text { Uniform load dis }} \\
& E_{3}=0.55 H_{i-1}[\mathrm{~mm}]
\end{aligned}
$$
where, $F_{\max }: 160 \mathrm{t}$ (calculated from rolling load equation $\left.F=H_{i-1} \cdot E / 60\right)$ $H_{i-1}$ : entrance thickness

$$
\begin{aligned}
& E_{1}=168.1 \cdot \tau_{M O} \cdot \text { torque ratio } /\left(\lambda_{a} R_{R E} \cdot H_{i-1}\right)[\mathrm{mm}] \\
& E_{2}=\left(F_{\max } \cdot 60 / H_{i-1}\right)^{2}[\mathrm{~mm}]
\end{aligned}
$$




\section{$R_{R E}:$ edger roll diameter \\ $\tau_{M O}:$ rated torque of moter \\ $\lambda_{a}:$ torque arm coefficient.}

The width variation at the exit of the roughing train is derived by considering the minimum and maximum width values of slab at the entrance.

The amount of edging is increased at a constant ratio with respect to the torque limit and is applied completely with respect to the buckling and load limits, as shown in Fig. 11. The model performs a learning according to the measured value of the roughing edger drive motor current, as shown in Fig. 12. The application of the model helped to expand the maximum range of slab width variation allowable at the hot strip mill by more than $10 \mathrm{~mm}$.

\section{Result of Application of Model}

The roughing edger setup model has been applied fully since its start-up. Slabs that have width variations of 10 to $35 \mathrm{~mm}$ and are not sized on a vertical scalebreaker can be accepted at the hot strip mill without impairment of product width accuracy.

\section{Conclusions}

The models and instrument developed as listed below helped to supply slabs from a continuous caster directly to a hot strip mill where a powerful vertical scalebreaker or width sizing mill is not available.

(1) A constant slab width control model to minimize the width variation of continuously cast slabs. (This model helped to reduce the width variation of the continuously cast slabs from 70 to $30 \mathrm{~mm}$.)

(2) The followings were developed to increase the allowable range of slab width variation at the hot strip mill, from 10 to $35 \mathrm{~mm}$.

1) A hot slab width meter of the contact type that is low in cost and high in accuracy to level the edge profile measurement of the slab.

2) A roughing edger setup model that can make the most of the small capacity of roughing edger.

\section{REFERENCES}

1) O. Tsubakihara: the 110th-111th Nishiyama Memorial Seminar, ISIJ, ed., ISIJ, Tokyo, (1986), 89; Trans. Iron Steel Inst. Jpn., 27 (1987), 81.

2) H. Matsunaga, M. Yoshii, S. Sadahiro, M. Saito and T. Fukuda: Seitetsu Kenkyu, (1984), No. 313, 1. 